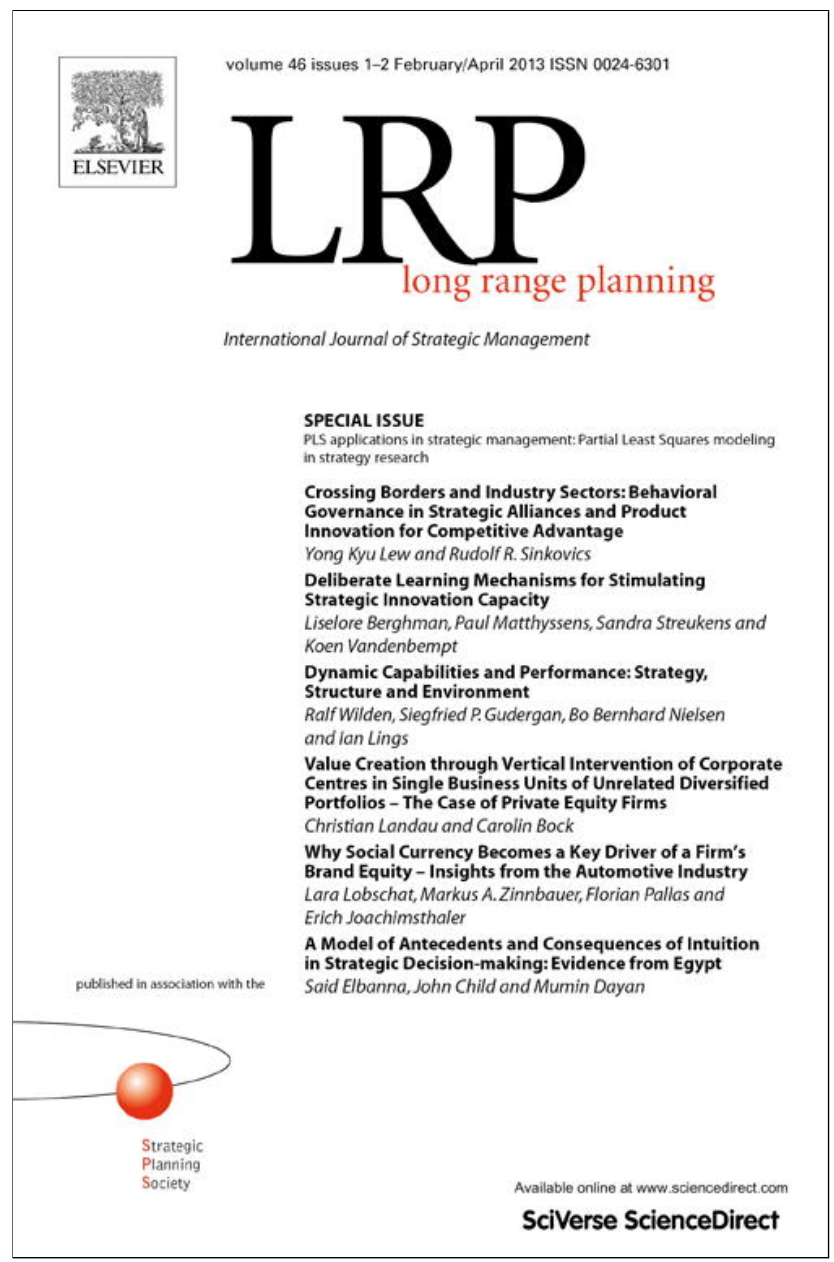

This article appeared in a journal published by Elsevier. The attached copy is furnished to the author for internal non-commercial research and education use, including for instruction at the authors institution and sharing with colleagues.

Other uses, including reproduction and distribution, or selling or licensing copies, or posting to personal, institutional or third party websites are prohibited.

In most cases authors are permitted to post their version of the article (e.g. in Word or Tex form) to their personal website or institutional repository. Authors requiring further information regarding Elsevier's archiving and manuscript policies are encouraged to visit:

http://www.elsevier.com/copyright 


\section{Crossing Borders and Industry Sectors: Behavioral Governance in Strategic Alliances and Product Innovation for Competitive Advantage}

\section{Yong Kyu Lew and Rudolf R. Sinkovics}

This paper investigates governance mechanisms in international technology alliances (ITAs), firm-level innovation capabilities, and performance outcomes in the mobile computing market. This high-tech market is characterized by numerous cross-border strategic technology collaborations between software and hardware firms.

Anchoring our work in interfirm governance theories and the resource-based view, we develop a model and empirically test relationships related to behavioral governance mechanisms, innovation capabilities, and business performance. In the cross-industry and cross-border context, the empirical model explains to what extent complementary strategic resources, through a relational governance mechanism, contribute to the innovation capabilities of high-tech firms, providing competitive advantage.

The data, analyzed using partial least squares (PLS) path modeling, indicates that technological commitment is a factor in expediting technology resource exchange in ITAs between heterogeneous firms. Technological commitment is captured by the extent to which a focal firm commits to investing its technology resources in an ITA to maintain the relationship. The results also show that firm-level performance is only influenced by market development capability, and not new product development capability, in product innovation. However, we did not find any significant moderating effects of firm size and industry type on the model.

This paper offers insights into how high-tech firms benefit from interfirm governance in international technology resource exchange arrangements. Furthermore, it provides 
evidence of the methodological usefulness of PLS path modeling in strategic alliance, capability and performance research.

(C) 2012 Elsevier Ltd. All rights reserved.

\section{Introduction}

The mobile computing market is characterized by contemporary innovative products (e.g., the Android Smartphone and the iPhone, the portable Netbook, and the tabular Touchbook). These cutting-edge devices exhibit innovative features that have changed market structures and customer behaviors within a relatively short time. The products are commercialized for the worldwide market by original brand manufacturers (OBMs) such as Motorola, HTC, Samsung, Apple, Acer, HP and Dell. However, at the upper end of this value chain, there are numerous players from different industries, that are internationally involved in the upstream value chain of the market.

For instance, the core hardware (HW) chip is designed by the UK-based ARM. By using ARM's core-technology, semiconductors such as Qualcomm in the US, integrate system-on-chips by outsourcing production to Taiwan-based foundries. System-level software (SW) is optimized and embedded by Finnish firms. The architectural operating system (OS) developed by Google's development networks is freely distributed to device manufacturers. On the top of the OS, SW platform developers (e.g., Adobe, RealNetworks, and Oracle) offer interfacing application platforms, such as Flash and Java, to HW and SW application firms. SW applications and user interfaces (e.g., office, multimedia, browsers, communications, touch screens) are developed over the HW and OS stacks, by SW application firms in various countries. Without understanding these international and cross-industry collaborations between firms from different industries in the upstream value chain of the market, Google's Eric Schmidt, at the upstream end, and Steve Jobs from Apple, at the downstream end, might not be able to create and capture value.

Certain knowledge and skills are embedded in the tangible and intangible resources of a firm (Grant and Baden-Fuller, 2004). In the end, these resources are embodied as certain forms of final products or services, contributing to the firm's value creation and competitive advantage in the market. It is the most worthy resources that should contribute to the firm's value creation. In this vein, a resource-based view regards valuable, inimitable, rare and non-substitutable (VIRN) resources as the origins of a firm's competitive advantage in the market. On the other hand, it is difficult for a firm to control its entire set of resources, in global high-velocity environments. What if the resources that are critical to a firm are not accessible in the local market? What if they are not available in the homogeneous industry of the firm? In such cases, firms often internationally cross industry lines in order to seek, access and acquire complementary resources in a constructive way (Gassmann et al., 2010; Glaister and Buckley, 1996; Kotabe et al., 2002).

International technology alliances (ITAs) allow a firm to extend its resource availability, thereby developing technologically innovative products (Danneels, 2002; Kotabe and Swan, 1995). From a Schumpeterian innovation perspective (Schumpeter, 1943), product innovation (e.g., new chipset design, the Android OS, or the Smartphone) allows a firm to open new markets (e.g., the mobile computing market) by changing the rules of the game in the market (e.g., Microsoft and Intel had previously dominated the personal computing market). From this perspective, the innovation capabilities of a firm are strategically important for creating competitive advantage.

Technology resource exchange governance mechanisms in ITAs play an important role in linking the external resources of a firm to its innovation-creating capabilities. As technology resource acquisition and protection are two sides of the same coin within ITAs (Das and Kumar, 2011; Das and Teng, 2000; Norman, 2004), proper interfirm governance mechanisms are critical in resolving this paradox. Recent studies on alliance governance mechanisms have shed light on two types: a contractual one, based on transaction cost economics; and a relational type, based on the relational view. However, the results of international strategic alliance governance studies based on the two theories remain ambiguous in terms of the extent to which the two mechanisms influence the performance of a firm (Faems et al., 2008; Hoetker and Mellewigt, 2009). 
Extant ITA governance studies in the strategy and international business literature theoretically link structural governance issues and other forms of collaboration, knowledge transfer, capability, performance, etc. (e.g., Mowery et al., 1996; Narula and Hagedoorn, 1999; Osborn and Baughn, 1990; Oxley and Sampson, 2004). These firm- or industry-level studies are mostly based on secondary data sources and thus capture constructs via proxies. While there are some behavioral firm-level papers which examine the above governance issues with primary data sources (see Sinkovics et al., 2010), the unique alliance context is not at the core of the analysis. The current paper takes a decidedly firm-level approach within the context of ITAs, examining behavioral aspects and drawing on transaction cost economics and the relational view. Essentially, this paper captures the impacts of external resource acquisition on a firm's innovation capabilities used to gain competitive advantage.

In the present study, we explore the linkages between three dimensions: behavioral ITA governance mechanisms, innovation capabilities, and business performance. In particular, we address the following questions: What kinds of behavioral governance mechanisms in cross-industry ITAs contribute to the innovation capabilities of firms in high-tech industries? To what extent do interfirm ITA governance mechanisms, developed between heterogeneous high-tech firms, influence innovation capabilities and, in turn, business performance? What are the roles of governance mechanisms and innovation capabilities in a firm?

Succinctly, we develop and test a model, thereby explaining to what extent interfirm behavioral governance mechanisms in ITAs affect firm-level innovation capabilities and performance outcomes. In order to fulfill the unique research contexts of cross-border and cross-industry technology alliances, we intentionally select the mobile computing market as a research setting. This market encompasses the most technology-intensive high-tech industries, that is SW and HW (see e.g., Department of Trade and Industry, 2006; Kotabe et al., 2002; Osborn and Baughn, 1990). This high-tech market is characterized by numerous ITAs between SW and HW firms in the upstream value chain.

This paper contributes to extending the present international strategic alliance literature, which has to date mostly highlighted relationships in the downstream, to the upstream value chain, in the context of technology resources and innovation. In the context of sectoral dyadic ITAs, we assess to what extent the technology resources obtained through ITA governance mechanisms affect firmlevel capabilities for product innovation, and in turn business performance. This paper shows that, in the technology resource exchange process, external technology resources internalized through relational governance mechanisms contribute to innovation capabilities. However, the superior business performance of a firm is realized only through its market development capabilities in the innovation funnel. The empirical results of our multi-group analysis are consistent in the overall model. Thus, our findings, based on industry managers' perceptions, support the theory that ITAs facilitate the product innovation processes of firms at the upper end of this value chain. Considering scarce international business literature on cross-border upstream $\mathrm{R} \& \mathrm{D}$ activities (Griffith et al., 2008; Kafouros et al., 2008), the current paper provides us with a better understanding of recent ITAs between heterogeneous high-tech firms in the mobile computing market.

The remainder of this paper is structured as follows. The second section reviews background theories, governance mechanisms, and innovation capabilities. The subsequent sections develop a conceptual model and hypotheses and explain research methods. In the following section we test the model using partial least squares (PLS) path modeling. The next section presents the results of the analysis. We conclude with discussions and conclusions.

\section{Governance mechanisms in the literature}

Strategic alliance structures are embodied in cooperative relationships between firms, taking forms such as joint ventures, minority equity alliances or contract-based alliances (Das and Teng, 2000). High-tech firms prefer to engage in non-equity-based international strategic alliances to access complementary resources, and quickly gain technological leadership positions in turbulent markets 
(Cantwell and Narula, 2001; Osborn and Hagedoorn, 1997). In the recent mobile computing market, SW and HW firms at the upstream end cooperate with each other to gain access to complementary technology resources (Lew and Sinkovics, 2012). Sectoral ITAs are viable vehicles which can support the firms in their request to acquire complementary resources and develop new products.

In this paper, we will limit ITAs to international, non-equity technology alliance forms; that is, joint R\&D agreements, co-development contracts, mutual technology sharing and technology licensing (Narula and Hagedoorn, 1999). Each governance structure has different levels of control hierarchies within the international strategic alliances, and thus firms entering the alliances have to develop governance mechanisms within the alliance structures in order to exchange resources (Gulati and Singh, 1998; Kumar and Patriotta, 2011; Weber and Mayer, 2011). With respect to governance mechanisms that are embodied in alliance governance structures, ITA governance mechanisms can be defined as relational and contractual salient constructs which contribute to the successful management of international technology resource exchange arrangements so as to attain the strategic goals of firms located in different nations. Recent alliance governance studies have been based on key theories such as the relational view and transaction cost economics.

\section{Relational view and commitment}

In order to investigate behavioral governance mechanisms in cross-industry ITAs, it is necessary to review the relational view in the literature. Most of the relational governance studies are underpinned by social exchange theory (e.g., Blau, 1964). This line of studies highlights the role of relational norms in social exchange; thus, it is not essential to specify obligations in contracts. The relational view basically assumes trustworthy behaviors between firms, drawn from social exchange theory (Faems et al., 2008). Hence, interfirm governance research based on the relational view incorporates relational norms (e.g., trust, commitment, cooperation, shared value, flexibility, and solidarity) within governance mechanisms.

As self-enforced governance mechanisms, relational norms play a lubricating role in interfirm relationships. Thus, relational norms contribute to expediting know-how, knowledge, and skill transfer between partners, thereby building up the capabilities of the firms (Dyer and Singh, 1998; Uzzi, 1997). In particular, there is anecdotal empirical evidence in the literature that trust is a wellresearched cooperative mechanism for managing conflict between partners (see Lee, 2009). The relational view is suitable for explaining relational ITA governance mechanisms given the effectiveness of exchanging technology resources between firms. A group of studies based on the relational view focuses on trust and commitment as the key relational capital in interfirm relationships (Cullen et al., 2000; Morgan and Hunt, 1994). The existence of high levels of trust in interfirm relationships means there is less need for safeguard mechanisms against a partner's opportunistic behavior (Gulati and Nickerson, 2008). In line with this, Madhok (2006, p. 36) states, "creation and sustenance of trust in a relationship requires a significant commitment of hard and soft resources."

In this paper, inspired by Kumar et al.'s work (1995) we highlight technological commitment of a firm to its ITA from a focal firm's willingness to invest the ITA and relationship continuance perspectives. Commitment is a party's best efforts in maintaining an ongoing relationship with the other party (Morgan and Hunt, 1994). One party's commitment to a specific relationship indicates its strategically-intentional resource allocation to that relationship. A firm's idiosyncratic investments in its partner contribute towards increasing the partner's perception of the firm's commitment (Anderson and Weitz, 1992). Commitment scholars explain continuance commitment as the maintenance of a long-term relationship between partnering firms (e.g., Anderson and Weitz, 1992; Kim and Frazier, 1997). Willingness to invest is another behavioral aspect of commitment (Kumar et al., 1995). In particular, willingness to invest is a more active type of commitment than continuance commitment in that it shows one party's eagerness to remain in a relationship, through its investment in the relationship. Partners' commitment inputs, such as critical information sharing and technology resource investment, contribute towards producing long-term commitment intentions (Gundlach et al., 1995). Commitment is an imperative relational governance mechanism in 
a strategic alliance, in that a firm's commitment to the alliance can be a signal to the other to show its readiness for strategic cooperation.

\section{Transaction cost economics and controls}

This paper links transaction cost economics theory to interfirm control mechanisms a remedy of protecting opportunistic behaviors from a partner (Granovetter, 1985; Williamson, 1979, 1991). Strategic alliance governance research emphasizes the hazards of knowledge leakage in conjunction with partners' opportunism (see e.g., Das and Rahman, 2010; Madhok, 1995; Oxley, 1997). Complex contractual forms can be a better governance solution in interfirm relationships than vertical resource integration, particularly when high asset specificity exists, but not enough to require the hierarchy mode (Mayer and Argyres, 2004). As such, the use of given external resources from partners through contracts makes a firm bring its technology resource transactions under a governance structure; that is, an ITA. This allows the firm to decrease the transaction costs in its resource exchange relationships. Therefore, transaction cost economics explains how contractual ITA governance mechanisms are used to protect opportunism and control the process of interfirm resource adaptation, from a behavioral economic perspective.

Governance studies based on transaction cost economics regard contract-based controls as appropriate interfirm governance mechanisms to minimize the likelihood of opportunism by a partner (Das, 2005; Oxley, 1997; White and Lui, 2005). Eisenhardt (1985) explains the applicability of behavior and outcome controls to organizational management: behavior-based control is appropriate when the behaviors of employees are observable and their tasks are programmable within a firm; otherwise, outcome-based control is a better control mechanism. In a similar vein, control mechanisms can be extended to interfirm governance based on contracts between legal parties; controls can play a role in protecting against opportunism and monitoring the processes and outcomes in a resource exchange relationship. Behavioral process control is related to the procedures or activities carried out to achieve a goal, whereas output control emphasizes monitoring performance standards or the final results (Heide, 1994; Jaworski, 1988). For this reason, relational risk is alleviated by behavior control, and performance risk by output control in strategic alliances (Das and Teng, 2001).

\section{Resource-based view and innovation-creating capabilities}

In the resource-based view, a firm's exploitation of VIRN resources contributes to achieving competitive advantage (Barney, 1991; Dyer and Singh, 1998; Oliver, 1997). A firm can attain a competitive heterogeneity through exchanging complementary technology resources external to the firm (Cantwell and Narula, 2001). Furthermore, extant literature suggests that firms benefit from collaborations through positive spillover effects (Kafouros and Buckley, 2008; Mesquita et al., 2008). The internalized resources acquired through exchange relationships make a contribution to a firm's capability of gaining relational rents for competitive advantage (Hitt et al., 2000; Lavie, 2006). Furthermore, valuable and rare resource acquisitions, derived from a firm's technological capability, allow the firm to increase the absorptive capacity that the firm's resource allocation for innovation rests upon (Cohen and Levinthal, 1990; Dyer and Singh, 1998; Newbert, 2008). The resource-based view helps us to illuminate the capabilities of product innovation in this paper, despite widespread criticism of the theory (see Kraaijenbrink et al., 2010). It explains not only resource internalization for innovation through external linkages (e.g., ITAs), from a resource-seeking focal firm's angle, but also the contribution of VIRN resources towards innovation-creating and value-capturing capabilities, which provide competitive advantage (Eisenhardt and Schoonhoven, 1996; Lavie, 2006; Pitelis, 2007).

The results of innovation range from small modifications to existing products to technological breakthroughs, new to the market (Goffin and Mitchell, 2005). New product development capability can be identified as a firm's ability to monitor and acquire required technology resources, align these resources to its own capacity, and develop marketable new products (Day, 1994; Teece and Pisano, 1994). From the resource-based view, new product development capability is built up 


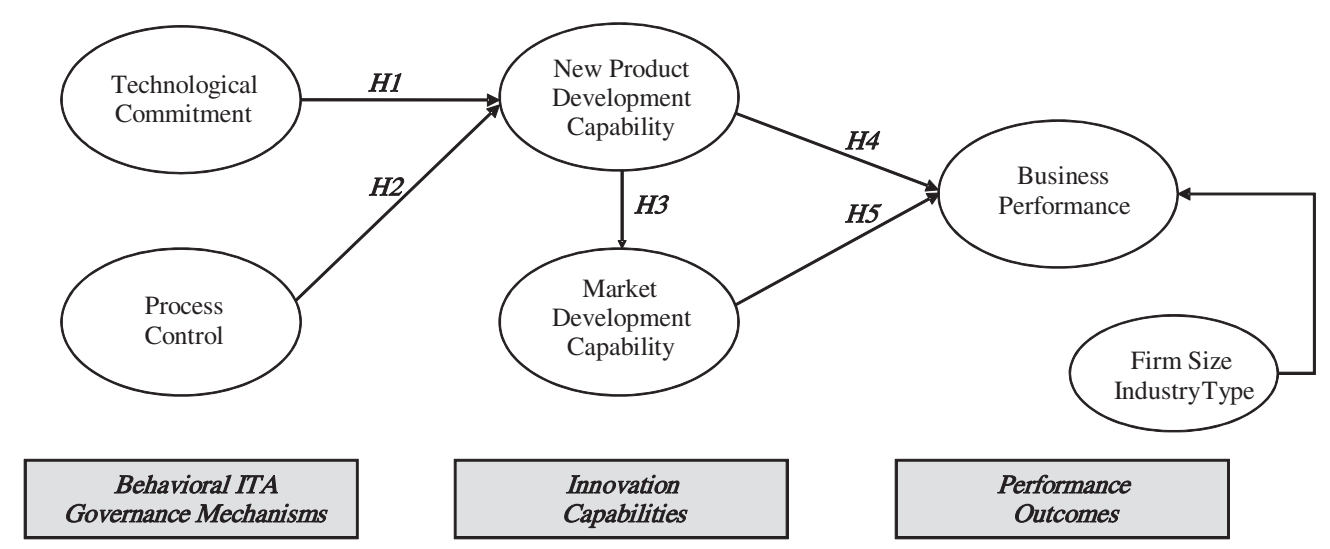

Figure 1. A conceptual model

through a blending process between the existing (internal) and the acquired (external) technology resources (Cohen and Levinthal, 1990; Eisenhardt and Tabrizi, 1995; Hill and Rothaermel, 2003). The innovation-oriented firm uses this capability to achieve competitive advantage. In this paper, we will limit our study of innovation to innovative new products which are new to the market or the firm; thus, we will exclude small modifications to existing products and small quality changes (Kleinschmidt and Cooper, 1991; Robertson and Gatignon, 1998).

New product development and market development are closely-related constructs. Technological innovation can contribute to the creation of a completely new market or to the expansion of an existing one (Abernathy and Clark, 1985; Jaworski et al., 2000). As such, a firm is able to generate new revenue streams, and save on development costs and time, by utilizing external technology resources for internal new product development (Chesbrough, 2007). The success of an innovative new product hinges upon a firm's ability to cope with unproven market contingencies (e.g., market preferences or market demand), particularly when the firm introduces the new product to the market (Burgers et al., 2008; Easingwood et al., 2006). Market knowledge and marketing proficiency also play critical roles in producing innovation outcomes that provide competitive advantage. This kind of market-related capability is a stepping-stone towards expediting the market growth of a firm. Market development capability contributes to (and in this paper we take it to indicate) a firm's creation of market opportunities and its commercialization of new products.

\section{Conceptual model and hypotheses}

The present study integrates and further extends earlier work. The proposed conceptual framework is illustrated in Figure 1. It shows the relationships between the three dimensions of ITA governance mechanisms, innovation capabilities and performance outcomes. Firstly, in terms of behavioral governance mechanisms, technological commitment is derived from the relational view, and process control from transaction cost economics. Secondly, the innovation capabilities dimension is developed as a linkage between the dimensions of governance mechanisms and performance outcomes. Furthermore, we split innovation capabilities into two distinct constructs, in order to empirically investigate the role of innovation capabilities in generating performance outcomes: new product development capability from the technological invention perspective, and market development capability from the commercialization aspect. Thus, the dimension of ITA governance mechanisms positively influences new product development capability. ${ }^{1}$ Finally, the dimension of innovation capabilities affects business performance.

\footnotetext{
1 The dimension of governance mechanisms does not have an impact on market development capability, as ITAs expedite interfirm technology resource transfers, not market-related resources. For this reason, we do not hypothesize about the relationships between technological commitment and process control and market development capability.
} 


\section{ITA governance mechanisms and new product development capability}

Strategic technology alliances enable partnering firms to establish competitive advantage by developing innovations through combinations of their acquired resources (Teng and Das, 2008). Technology alliances are the most effective strategic option for new product development in high-tech firms. A close relationship between partners, and resource allocation through relational capital, allows them to surmount difficulties in new product development (Song and Parry, 1997). A high degree of dependence between partners results in more longterm oriented normative contracting, based on mutual expectation and understanding (Lusch and Brown, 1996).

Relational governance mechanisms can contribute towards new product development, in that relational capital expedites technology resource exchange and reduces the transaction costs between partners. Commitment to technology resource investment results in successful innovative product development in a firm (Miller, 1987; Stanley, 2008). In the interfirm relationship context, technological commitment to ITAs brings required resources together with firms' capabilities, thereby enabling them to produce incremental or breakthrough innovation (Becker and Dietz, 2004; Li and Ferreira, 2008). A firm's technological commitment to an ITA signifies its willingness to engage in technological cooperation with its partner. Furthermore, apart from keeping to the stipulated legal terms and conditions in the contract, one party's proactive attitudes (e.g., key information sharing and problem-solving efforts) can be perceived as commitment by the other party. Firms participating in an emerging high-tech market (e.g., the mobile computing market) need complementary technology resources from other firms, thus gains heterogeneity of benefits (Lavie et al., 2007; Lew and Sinkovics, 2012). Furthermore, reliance on partners' resources between their boundary spanners requires technological resource commitment for corporation in ITAs (Luo, 2005). As a result, firms that need to obtain complementary technology resources through ITAs are likely to be willing to invest in such relationships and strategically commit to maintaining them. Through technological commitment, the technology resources required for product innovation are properly transferred to partners, enhancing the new product development capabilities of high-tech firms. Hence:

H1. Technological resource commitment to an ITA - which can be seen as a relational governance mechanism in the context of high-tech industry - positively influences a firm's new product development capability.

In the high-tech industry, proper product development process management is one of the key success factors when making innovative products (Griffin, 1997). Operational effectiveness in the product development process (e.g., development time, productivity, or flexibility) contributes to building innovation-creating capabilities. On the other hand, such a process incurs risk as a firm has to spend a large amount of technology resources in managing the product development (Clark and Fujimoto, 1991; Cooper, 2001). Thus, it is critical to control the quality of new product development in order to reduce the risk (Kleinschmidt and Cooper, 1991).

Drawing on transaction cost economics, a focal firm needs to manage its new product development process in ITAs so as to protect itself from contractual hazards incurred through its partner (Das, 2005; Mayer and Salomon, 2006). As such, process control based on a detailed contract in an ITA is an efficient governance mechanism through which a firm can build its new product development capabilities. In ITAs, partners stipulate key terms and conditions in the contract (e.g., roles, responsibilities and scope). Mutually agreed contractual forms between the partners ensure visibility in the complex technology development and implementation process (e.g., monitoring the product development process, technology quality, and development milestone for the final deliverable). Thus, detailed contractual forms alleviate the risks inherent in product development through ITAs (Carson et al., 2006; Mayer and Argyres, 2004; Poppo and Zenger, 2002). By following this logic, process control makes a contribution towards resolving future product development risks 
in ITAs, thereby enabling partners to build new product development capabilities for product innovation.

H2. Process control in an ITA - which can be seen as a contractual governance mechanism positively influences a firm's new product development capability.

\section{New product development capability and market development capability}

Internalized external technology resources within a firm's boundary have an impact on its technological capability and market success (Li and Atuahene-Gima, 2002). A technology-oriented firm's strong new product development capability will allow it to create innovative products. However, such capability is a necessary but insufficient condition for superior market performance. As firms spend a large amount of time and effort on any new product launch, market development capability (e.g., market monitoring, linking and launching) plays a critical role in leveraging their technological capabilities to generate revenue (Song et al., 2005). A firm's market development efforts for its newly developed products will significantly influence their market performance (see e.g., Burgers et al., 2008; Debruyne et al., 2002; Ramaswami et al., 2009).

Based on the resource-based view, external technology resources, permeated through resource exchange governance mechanisms in ITAs, enable a firm to enhance its new product development capability. Product innovation necessitates both technological capability and market-related capability, which comprise different resource bases (Danneels, 2002; Song et al., 2005). A firm cannot commercialize the outcomes of new product development in the market without having valuecapturing abilities as well (Gans and Stern, 2003; Littler, 1994). In the new product development funnel, firms initially focus on technological activities (e.g., new design, project refinement, $\mathrm{R} \& \mathrm{D}$, and knowledge sharing with external partners) in the product development stage and later highlight value-capturing commercialization activities (Birkinshaw and Sheehan, 2002; Burgers et al., 2008; Cohen et al., 1996). For this reason, new product development capability of a firm can thus invigorate its market development capability; i.e., to explore new markets. Hence, firms with technologically innovative products require high levels of market development capability (Bradley, 1999; Dodgson et al., 2008). Also, firms with higher new product development capability could have a stronger incentive to invest in market development capability.

\section{H3. A firm's new product development capability gained through its ITAs is positively related to its} market development capability.

\section{Innovation capabilities and performance outcomes}

Strategic technology alliances expedite the R\&D investment and technology innovation of a firm (Hagedoorn and Schakenraad, 1994). Having technologically innovative partners encourages a firm to achieve a high rate of sales growth in a high-tech industry (Stuart, 2000). The operational and financial performance of a firm is related to both its technology development and its market-related capabilities (Kotabe et al., 2002). Thus, innovation capabilities, which are defined as product and market development in this paper, have an impact on the business performance of a firm. New product development capability, attributable to ITAs and accruing from acquired resources, can contribute to the development of technologically innovative products. Particularly, comparing with low-tech industries (e.g., commodity goods), technology-intensive firms in high-tech industries (e.g., mobile computing SW and HW) have a propensity to invest heavily in $\mathrm{R} \& \mathrm{D}$ and new product development for returns on technological investment (see e.g., Kirner et al., 2009; Neelankavil and Alaganar, 2003). Meanwhile, market development capability facilitates the launch of innovative products in the market (Adams et al., 2006; Liao and Rice, 2010).

As the outcomes of new product and market development capabilities, financial and operational performance and overall effectiveness can be used to capture business performance (Venkatraman and Ramanujam, 1986; Zahra et al., 2000). Operational performance is associated with the non- 
financial performance of a firm. This embraces the operational outcomes of product innovation within the domain of business performance (Lee and Cavusgil, 2006). Financial performance can be related to explicit economic outcomes attributable to innovation capabilities (e.g., sales growth, profitability, return on investment and return on sales) (Venkatraman and Ramanujam, 1986; Zahra et al., 2000). Furthermore, the results of product innovation influence the firm-level overall effectiveness (e.g., a firm's increased reputation in the market and a firm's overall perceived performance). Thus, we hypothesize that innovation capabilities have an impact on the multidimensional performance outcomes of a firm.

\section{H4. A high-tech firm's new product development capability positively influences business performance. \\ H5. A high-tech firm owning a high level of market development capability leads to higher business performance.}

\section{Research method}

\section{Exploratory interviews and sampling frame}

As an initial step, we conducted semi-structured interviews with eight senior managers from HW and SW firms to inform a subsequent survey-based approach. The results of the interviews helped formulate the constructs in the conceptual model in Figure 1. The context of this research is ITAs between SW and HW firms, and a focal firm's innovation capabilities and performance. Regarding this research context, it was difficult to obtain the correct sampling frame from a large database due to the newness of the market and the lack of specified industry code classifications (e.g., NACE REV).

Thus, purposive non-probability sampling was selected to exclude firms irrelevant to the research context. Firstly, we defined sample IT firms as SW (i.e., user interface, applications, application platforms, operating systems/low-level systems, and development) and HW (i.e., system-onchips, chipset design, microcontrollers, communications, and video/graphics). Secondly, a sampling frame was developed using publicly available global partner lists of dominant firms in the market. Finally, based on the interviews with senior managers, we complemented the sampling frame by including lists of exhibiting firms at world-class IT exhibitions: the Mobile World Congress in Spain and, separately, Computex in Taiwan, 2011. The final sampling frame comprised $350 \mathrm{HW}$ and 529 SW IT firms, a total of 879 case firms.

\section{Data collection}

Through the sampling process, we obtained the e-mail addresses of case firms, including key informants' e-mail addresses. In order to ensure the representativeness of the informants and increase the response rate, identified senior managers were pre-contacted and connected through a networking website, LinkedIn. We chose senior managers who were engaged in ITAs in their firms as informants (e.g., alliance management, business development, product management VPs/directors/ senior managers). Based on the conducted interviews and the LinkedIn connections, we judged that these functional managers were in the most informed positions in the firms to understand both ITAs and firm-level innovation capabilities. Furthermore, on the first page of the questionnaire, we asked the respondents to also forward a copy to the most appropriate manager within their organization. In every question of the questionnaire, we provided definitions of each of the key constructs.

The data were collected for twelve weeks, using two methods: online and face-to-face surveys. E-mails were distributed to each of the 879 case firms. In the third week following the first e-mail, follow-up e-mails were sent and non-respondents were contacted by telephone. This process was repeated at the end of the twelve weeks. In parallel with this, we collected data through face-to-face meetings with key informants during the Computex IT exhibition in Taiwan. Out of the 879 firms, nine refused to respond to the questionnaire and 94 questionnaires were not 
delivered for various reasons (e.g., bankruptcy, incorrect e-mail addresses). This decreased the number of valid case firms from 879 to 776 . We received 121 completed questionnaires but excluded eleven that were unusable, leaving 110 valid, completed questionnaires. Hence, the usable response rate is $14.2 \%(110 / 776)$. The characteristics of the respondent firms are summarized in the Appendix.

\section{Measurement}

In order to respond to what extent interfirm behavioral governance mechanisms in ITAs affect firm-level innovation capabilities and performance outcomes, multiple-item scales were used to measure all of the constructs in the model. Proven measures were adapted from top journals to secure content validity.

\section{Independent variables}

Technological commitment was conceptualized as a firm's willingness to invest its technological knowledge and skills to an ITA to maintain the relationship (Li and Ferreira, 2008). A five-item scale, adapted to the context of ITAs, was derived from Kumar et al. (1995) and Gundlach et al. (1995). Process control was defined as the extent to which a firm monitors the product development process performed by its partner in order to achieve the desired deliverables in an ITA (Aulakh et al., 1996). Four items were adapted from the scales developed by Kirsch et al. (2002) and Heide et al. (2007).

\section{Dependent variables}

New product development capability was defined as a focal firm's technological abilities to develop innovative products which are new to the market or the firm, in terms of monitoring the new technology resources required by the firm, integrating these resources with its own technologies and developing marketable new products (Kleinschmidt and Cooper, 1991). Five items were drawn from the works of Zhou and Wu (2010) and Calantone et al. (2002). Market development capability was conceptualized as a firm's market-creating and new product commercializing abilities, used to expand the current market and develop new markets (Day, 1994). Five items were adapted from the works of Song et al. (2005) and Atuahene-Gima (2005).

Business performance was defined as financial, operational, and overall performance, following Venkatraman and Ramanujam (1986). It was measured using subjective items from primary sources related to the firms. This approach allowed us to measure composite and comprehensive business performance. A large number of research results in the literature justify the use of perceptive measures of performance (see e.g., Dess and Robinson, 1984; Jean et al., 2010; Li and Atuahene-Gima, 2002). Furthermore, the literature supports perceptual performance measurement for cross-industry and alliance research (Brettel et al., 2011; Pagell and Krause, 2004; Song et al., 2005). Seven indicators were used to measure the multiple dimensions of business performance: sales growth, increased profit, growth in market share, increased number of official new products launched, increased number of customers, increased reputation in the market, and increased overall performance.

\section{Control variables}

Firstly, we controlled for firm size when investigating the relationships between innovation capabilities (new product capability and market development capability) and business performance, to investigate to what extent these relationships are moderated by firm size. Secondly, industry type was controlled for as we assume that causal relationships in the conceptual model may differ depending on the sectoral characteristics of firms. In this respect, we designed the survey so as to intentionally split SW and HW firms in the sampling frame.

\section{Bias tests}

Following the approach of Armstrong and Overton (1977), non-response bias among the respondents in the online survey was examined by comparing early with late respondents on all 26 items in 
the model. The results of a t-test showed no significant differences in the means of all items between the two groups $(\mathrm{p}<0.05)$, suggesting that there is no large non-response bias in the data. Furthermore, a more stringent non-response bias test was conducted for the data from the online survey and the face-to-face field survey at Computex, to determine whether there is any bias related to the data collection methods. In order to look for differences between the data, we compared 57 responses to the online survey with 53 from the field survey, using t-tests on all items. The results indicated no significant differences between the two groups $(\mathrm{p}<0.05)$. Thus, there is no evidence of any obvious bias related to the data collection methods.

There is likely to be common method bias (CMB) because the data for the dependent and independent variables were gathered using the same survey instrument from single informants. In order to tackle this, CMB was examined using Harman's one-factor test (Podsakoff and Organ, 1986). The results of an unrotated principal component analysis showed that the first factor explains only $20.6 \%$ of the total variance of $79.4 \%$. Since no single dominant factor emerged, CMB can be assumed not to be an issue in the data. Furthermore, a more elaborate partial correlation analysis was conducted between the sales revenue data from the respondents and secondary sales data from DataStream. The results showed a strong correlation of $98 \%$ between the two. Thus, we assume that CMB does not adversely affect our research findings.

\section{PLS path modeling}

PLS path modeling was chosen for the data analysis. PLS is a variance-based structural equation modeling technique, suitable for structural measurement models, small-sized samples, and explorative research aimed at testing and validating models (Hair et al., 2011b; Hair et al., 2012; Henseler et al., 2009). To the best of our knowledge, the research setting of ITAs between HW and SW firms in the mobile computing market has not yet been studied in the international business and strategy literature; the concept of innovation capabilities has not been fully explored by perceptively measuring firm-level new product and market development capabilities in the innovation and strategy management literature; finally, it seems that studies of behavioral interfirm governance mechanisms, which have focused on downstream relationships in the marketing context, are unlikely to highlight upstream cross-border relationships in the technology context. The model and research setting have explorative natures, and thus require a soft modeling approach (Wold, 1975). In addition, taking reflective latent variables of all constructs, and the relatively small sample size $(\mathrm{n}=110)$, into account, we judged that PLS path modeling was the most appropriate technique for data analysis (Barclay et al., 1995). We took a two-step analytical approach: first, the assessment of the measurement model and then of the structural model (Hair et al., 2012; Hulland, 1999). The logic behind this approach is that the reliability and validity of the measurement model guarantee that the results of the structural model can be used to draw conclusions. We analyzed the data using SmartPLS 2.0 (Ringle et al., 2005).

\section{Results of analysis}

\section{Reliability and validity of measures}

Internal reliability was examined via Cronbach's alpha and composite reliability (CR). All constructs had alpha values above 0.7 . This suggested a high level of internal consistency reliability. The CR values of the constructs ranged from 0.820 to 0.908 , all greater than the threshold of 0.7 (Bagozzi and Yi, 1998). Indicator reliability was examined by measuring the outer loadings on all items in the model. The absolute standardized outer loadings ranged from 0.508 to 0.910 (see the Appendix). A score for the outer loading over 0.5 can be acceptable when other items measure the same construct (Chin, 1988). These figures guarantee that reliable measurements are being taken in the model. Discriminant validity was examined using the square root of average variance extracted (AVE) and cross-loadings. As shown in Table 1, the values of the square root of AVE for 


\begin{tabular}{|c|c|c|c|c|c|}
\hline & 1 & 2 & 3 & 4 & 5 \\
\hline 1. Technological commitment & 0.709 & & & & \\
\hline 2. Process control & 0.504 & 0.844 & & & \\
\hline 3. New product development capability & 0.448 & 0.266 & 0.694 & & \\
\hline 4. Market development capability & 0.292 & 0.153 & 0.387 & 0.742 & \\
\hline 5. Business performance & 0.138 & 0.231 & 0.121 & 0.476 & 0.714 \\
\hline
\end{tabular}

Note: bold diagonal figures are the square roots of AVE.

each construct were greater than the highest correlation between that construct and the other constructs (Fornell and Larcker, 1981). Furthermore, we assessed discriminant validity by comparing the loading values of each indicator with the cross-loadings with other reflective indicators (Chin, 1988). The indicator loadings were all higher than the cross-loadings, suggesting satisfactory discriminant validity in the model.

Convergent validity was assessed by measuring AVE (Fornell and Larcker, 1981). All constructs showed AVE values greater than the 0.5 threshold, except for new product development capability (see the Appendix). Its AVE was 0.481 which is slightly lower than 0.5. However, the values of CR, the square root of AVE, and the cross-loading showed that new product development capability does measure the technological product development abilities of HW and SW firms sufficiently. For this reason, we decided to retain new product development capability in the model.

\section{The predictive power of the model}

The predictive power of the model was analyzed using $\mathrm{R}^{2}$. Using the PLS Algorithm function in SmartPLS 2.0, we computed the $\mathrm{R}^{2}$ statistics of the three endogenous constructs in the model. The $\mathrm{R}^{2}$ values of new product development capability, market development capability and business performance were respectively $0.203,0.150$ and 0.231 (see Table 2) all of which are greater than the acceptable threshold of 0.1 (Falk and Miller, 1981). Considering the international and sectoral research contexts, these $\mathrm{R}^{2}$ values are satisfactory.

The effect size of $f^{2}$ was computed using the following formula: $f^{2}=\left(\mathrm{R}_{\text {included }}^{2}-\mathrm{R}_{\text {excluded }}^{2}\right) /$ $\left(1-\mathrm{R}_{\text {included }}^{2}\right)$. The $f^{2}$ analysis complements $\mathrm{R}^{2}$ in that the effect sizes of the impact of specific latent variables on the dependent latent variables can be examined (Chin, 2010). $f^{2}$ values of $0.02,0.15$ and 0.35 respectively were used as guidelines for small, medium and large effect sizes of the predictive variables (Cohen, 1988). We found a medium effect size of new technological commitment

Table 2. Effect sizes of the latent variables

\begin{tabular}{|c|c|c|c|}
\hline & $\mathbf{R}^{2}$ & $f^{2}$ & Effect size rating \\
\hline New product development capability & 0.203 & & \\
\hline Technological commitment & - & 0.165 & Medium \\
\hline Process control & - & 0.001 & Very small effect \\
\hline Market development capability & 0.150 & & \\
\hline Technological commitment & - & 0.220 & Medium \\
\hline Business performance & 0.231 & & \\
\hline New product development capability & - & 0.008 & Very small effect \\
\hline Market development capability & - & 0.250 & Medium \\
\hline
\end{tabular}


$\left(f^{2}=0.165\right)$ but a very small effect size of process control on new product development capability. New product development capability had a medium effect on market development capability $\left(f^{2}=0.220\right)$. Finally, there is a medium effect of market development capability $\left(f^{2}=0.250\right)$ on business performance but a very small effect of new development capability on business performance. Table 2 summarizes the respective effect sizes of the latent variables at the structural level.

We assessed the predictive relevance of the three endogenous constructs using Stone-Geisser's $Q^{2}$ statistic (Geisser, 1975; Stone, 1974), based on the fact that all the endogenous latent constructs were reflective measurement model. By following the blindfolding and jack-knife re-sampling approaches, the predictive power of the model was examined by means of Stone-Geisser's $Q^{2}$, crossvalidated index (Chin, 1988; Tenenhaus et al., 2005; Wold, 1975). We computed two types of crossvalidated redundancy $Q^{2}$ and cross-validated communality $Q^{2}$ (Fornell and Cha, 1994). The $Q^{2}$ values of all latent constructs were greater than zero, suggesting the predictive relevance of the model (Chin, 1988).

\section{Hypothesis testing}

In order to test the hypotheses, we examined the significance of the path coefficient estimates on for the seven paths in the model. We used a bootstrap technique, which produces more reasonable standard error estimates (Tenenhaus et al., 2005). Following Hair et al. (2011a), we set 5,000 resampling with replacement from the number of bootstrap cases equal to the original number of 110 observations to generate standard errors and obtain t-statistics.

The path coefficient from technological commitment to new product development capability is $0.422(\mathrm{t}=3.974, \mathrm{p}<0.001)$. Thus, $\mathrm{H} 1$ is supported. H2 is not supported because the path coefficient from process control to new product development capability is not significant (coefficient $=0.052$ ). The path coefficient from new product development capability to market development capability is $0.387(\mathrm{t}=4.011, \mathrm{p}<0.001)$. This positive relationship supports $\mathrm{H} 3$. The direct impact of new product capability on business performance is not significant (coefficient $=-0.074$ ). Thus, H4 is not supported. Finally, the path coefficient from market development capability to business performance is $0.505(\mathrm{t}=5.304, \mathrm{p}<0.001)$, which supports H5. If we ignore market development capability in the original model, the relationship between new product development capability and business performance (H4) is not significant (coefficient $=0.198$ ). The results indicate that the relationship between new product development capability and business performance is not mediated by market development capability (Baron and Kenny, 1986). In other words, these two capabilities are not sufficient but necessary conditions for business performance. Figure 2 illustrates the assessed structural model and Table 3 summarizes the results of the hypothesis tests.

\section{Post hoc analysis: comparisons based on firm size and industry type}

There can be a heterogeneity issue in models analyzed using PLS in that "different population parameters are likely for different subpopulations" (Henseler et al., 2009, p. 307). In order to tackle

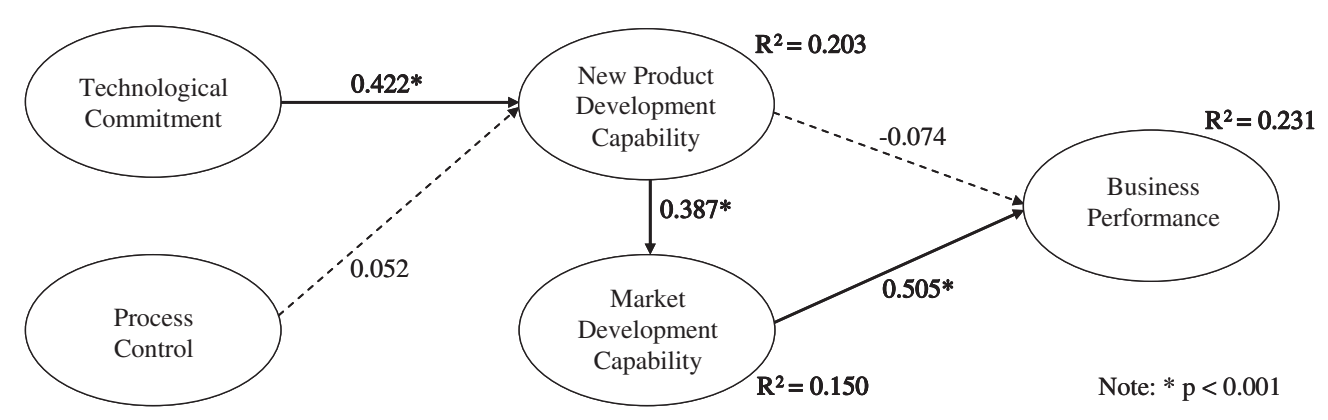

Figure 2. Assessment of the structural model 


\begin{tabular}{lccl} 
Paths & $\begin{array}{l}\text { Standardized } \\
\text { coefficient }\end{array}$ & t-statistic & $\begin{array}{l}\text { Supported alternative } \\
\text { hypothesis }\end{array}$ \\
\hline H1. Technological commitment $\rightarrow$ NPD capability & $0.422^{\star}$ & 3.974 & Yes \\
H2. Process control $\rightarrow$ NPD capability & 0.052 & 0.461 & No \\
H3. NPD capability $\rightarrow$ MD capability & $0.387^{\star}$ & 4.011 & Yes \\
H4. NPD capability $\rightarrow$ Business performance & -0.074 & 0.588 & No \\
H5. MD capability $\rightarrow$ Business performance & $0.505^{\star}$ & 5.304 & Yes
\end{tabular}

Note: ${ }^{\star} \mathrm{p}<0.001$, new product development (NPD), market development (MD).

the potential heterogeneity of the observations subject to various contingencies, an additional multi-group analysis was conducted by controlling for firm size and industry type.

Firm size may be related to product innovation and performance in high-tech industries (Lunn, 1987). It has been shown that firm size is significantly related to product innovation output (Camison-Zornonza et al., 2004; Gatignon and Xuereb, 1997; Spanos and Lioukas, 2001). Larger firms generate better new product performance in the market as they have more utilizable internal technology resources and greater market development capabilities than small and medium-sized enterprises (SMEs). Thus, we controlled for firm size in the relationships between the firm-level dimensions of innovation capabilities and business performance. The original 110 sample firms were categorized into two groups: large firms $(n=60)$ and SMEs $(n=50)$. The criterion used to divide the sample is consistent with the European Commission's (2003) definition of SMEs as firms with less than 250 employees. The $\mathrm{R}^{2}$ values of business performance were 0.231 for large firms and 0.313 for SMEs, indicating the predictive power of the two sub-group models. The results of the group comparison based on firm size showed that the path from new product development capability to business performance was not significant for either group (see Table 4). The direct impact of market development capability on business performance was significant for large firms $(t=3.054, p<0.01)$ and for SMEs $(\mathrm{t}=2.451, \mathrm{p}<0.05)$. Results were consistent with the overall model at the 0.05 significance level. Hence, firm size does not significantly moderate the relationships between innovation capabilities and business performance.

In order to investigate the moderating effects of industry type on the model (see Figure 1), the 110 sample firms were divided into two groups: HW $(n=58)$ and SW $(n=52)$. Table 5 summarizes the PLS path estimates and the $\mathrm{R}^{2}$ values of the endogenous constructs for group comparisons based on industry type. The $\mathrm{R}^{2}$ values of the endogenous constructs for both groups ranged from 0.135 to 0.352 , suggesting the model is acceptable according to the threshold of 0.1 . Then, we

Table 4. Comparison based on firm size

Overall model Large firms $(n=60) \quad$ SMEs $(n=50)$

\begin{tabular}{|c|c|c|c|}
\hline \multicolumn{4}{|l|}{$\mathbf{R}^{2}$} \\
\hline Business performance & 0.231 & 0.231 & 0.313 \\
\hline \multicolumn{4}{|l|}{ Paths } \\
\hline $\boldsymbol{H}$ 4. NPD capability $\rightarrow$ Business performance & -0.074 & -0.098 & -0.080 \\
\hline H5. MD capability $\rightarrow$ Business performance & $0.505^{\star * *}$ & $0.510^{\star *}$ & $0.587^{\star}$ \\
\hline
\end{tabular}

Note: ${ }^{\star} \mathrm{p}<0.05,{ }^{* *} \mathrm{p}<0.01,{ }^{* *} \mathrm{p}<0.001$, new product development (NPD), market development capability (MD). 


\begin{tabular}{lllll}
$\begin{array}{l}\text { Overall } \\
\text { model } \\
(n=110)\end{array}$ & HW & SW & Difference & t-statistic \\
$(n=58)$ & $(n=52)$ & $|\mathrm{HW}-\mathrm{SW}|$ & $(d f=108)$ \\
\hline
\end{tabular}

$\mathbf{R}^{2}$

NPD capability

$\begin{array}{lll}0.203 & 0.135 & 0.352\end{array}$

MD capability

$\begin{array}{lll}0.150 & 0.191 & 0.219\end{array}$

Business performance

$\begin{array}{lll}0.231 & 0.289 & 0.239\end{array}$

Paths

H1.Technological commitment $\rightarrow$ NPD capability

H2. Process control $\rightarrow$ NPD capability

$0.422^{* * *} \quad 0.365$

$0.500^{* *} \quad 0.135$

$\begin{array}{llll}0.052 & 0.005 & 0.134 & 0.129\end{array}$

0.413 (n.s)

H3. NPD capability $\rightarrow$ MD capability

$\begin{array}{llll}0.387^{* * *} & 0.437^{* *} & 0.468 & 0.032\end{array}$

0.540 (n.s)

H4. NPD capability $\rightarrow$ Business performance

$-0.074$

$-0.129$

$-0.148$

$0.505^{* * *}$

$0.581^{* * *}$

0.019

0.108 (n.s)

H5. MD capability $\rightarrow$ Business performance

$0.540^{*}$

0.041

0.057 (n.s)

0.146 (n.s)

Note: ${ }^{\star} \mathrm{p}<0.05,{ }^{\star *} \mathrm{p}<0.01,{ }^{\star *} \mathrm{p}<0.001, d f$ (degree of freedom), new product development (NPD), market development (MD), n.s (not significant).

compared the HW and SW groups using a parametric approach (Keil et al., 2000). Through 5,000 bootstrapping, we obtained the standard errors of the structural paths in the two groups. Then, the differences between the path coefficients were tested using t-statistics. The path from technological commitment to new product development capability was found to be significant for the SW group $(\mathrm{t}=3.074, \mathrm{p}<0.01)$ but not for the HW group (coefficient $=0.365)$. The impact of new product development capability on market development capability was significant in the HW group $(\mathrm{t}=2.701, \mathrm{p}<0.01)$ but not significant for the SW group (coefficient $=0.468)$. However, the results of the t-tests revealed that these differences between the two groups were not significant (see Table 5), indicating that there are no significant moderating effects on the model from industry type.

\section{Discussion and conclusions}

\section{Technological commitment to the relationship}

Our theoretically integrative model provides a link between two dimensions, ITA governance mechanisms and performance outcomes, by means of a third dimension, innovation capabilities. The results support relationships between governance mechanisms, innovation capability and business performance. This is consistent with the argument of Hagedoorn and Schakenraad (1994): technology alliances have no direct relationship with a firm's performance but technology innovation led by strategic technology alliances contribute to business performance. From a behavioral perspective, the findings offer deeper insights into the chain of causalities: technology resource exchange, through relational governance mechanisms in ITAs, contributes to firm-level business performance via the results of innovation capabilities.

Surprisingly, only technological commitment has an effect on new product development capability in the model. The results are in line with the arguments of a group of studies based on the relational view of governance mechanisms in interfirm relationships (Dyer and Singh, 1998; Li and Ferreira, 2008; Uzzi, 1997; Wu et al., 2007). At a theoretical level, this contributes to discussions which are related to the extended resource-based view in strategy management. Relational rents generated from ITAs strongly affect innovation capabilities from a focal (ego) firm's perspective. This cements the integration of theories from the resource-based 
view and the relational view in the strategy management literature (Gulati et al., 2009; Lavie, 2006; Mesquita et al., 2008).

As for the insignificant association between process control and new product development capability, the lack of empirical support for the relationship could be related to the context of ITAs in this paper. ITAs between heterogeneous foreign high-tech firms (i.e., SW and HW) may obviate the need for the process control of the complex and mutually adaptive new product development processes (Koza and Lewin, 1998; Mayer and Salomon, 2006). Given this, relational governance mechanisms such as technological commitment of each partner to an ITA may be more germane and pertinent relative to contract-based process control mechanisms in ITAs.

\section{Non-complementary governance mechanisms}

Another finding is that relational and contractual governance mechanisms are not complementary in cross-industry ITAs in view of the fact that there are no associations between process control and innovation capabilities. Thus, the findings may assist us to resolve the ambiguity in previous strategic alliance studies related to whether these two governance mechanisms are complementary or substitutable.

Interestingly, in the current study a governance mechanism derived from relational norms is a more effective choice than a contract-based process control in achieving business performance (Deligonul and Cavusgil, 2006; Zaheer and Venkatraman, 1995). The results can be interpreted as showing that complementary resource exchange between heterogeneous industries may alleviate the need for protective contractual governance mechanisms. As such, complementary resource dependence on a partner from a different sector may necessitate a focal firm's technological commitment to the relationship. As a relational governance mechanism, the technological commitment of the focal firm strengthens the relationship. This relational bonding mechanism allows the firm to internalize particular complementary technology resources, which enhance its innovation-creating capability.

\section{Role of new product development and market development capability: a more complex re-} lationship than initially conceived

The results strongly support the idea that market development capability plays a role in linking new product development capability to a firm's superior performance. However, the direct effect of new product development capability on business performance is not significant for any of the investigated models. The strong impact of market development capability on the effect new product development capability has on business performance demonstrates the criticality of market-related capabilities to the product innovation process of a firm. In other words, they do not supplant but complement each other. Technologically excellent innovative products can only penetrate the market successfully when accompanied by sufficient market development capability. Market development capability is a cornerstone of high-tech firms' achievement of superior performance (Liao and Rice, 2010; Vorhies et al., 2009).

Another important aspect of this paper is that we empirically explore the notion of innovation; that is, technological invention leading to market commercialization. The significant relationship between new product development capability and market development capability in all the investigated models implies that market development is critically important even for technologyintensive high-tech firms. This is in line with the conceptual arguments of scholars from different disciplinary areas in business and management, such as open innovation (Chesbrough, 2004; Lichtenthaler, 2008), product innovation (Danneels, 2002), and the market-driving (Jaworski et al., 2000) approaches in the marketing context.

\section{Fundamentally essential new product development and market development capabilities}

The findings may help us to understand the moderating effect of firm size on product innovation. Although firm size is one of the most frequently used control variables in the strategy and innovation literature, previous results seem inconsistent. Firm size does not impact on 
the relationship between innovation capabilities and business performance. A recent study by Kafouros et al. (2008) shows quite similar results to the current study: the innovation performance of large firms with low levels of internationalization is no higher than that of their market competitors. There is an interesting empirical report that firm size is not positively related to the contribution of external R\&D (Kafouros and Buckley, 2008). Our findings may be due to the predefined concept of innovation capabilities in this study. We only investigate product innovationrelated capabilities from technological and market development perspectives in this research. Firm size may be more positively related to process innovation than product innovation, as large firms can gain greater benefits through investing in process innovation than small firms (Baldwin and Lin, 2002; Berry and Taggart, 1994; Fritsch and Meschede, 2001). Furthermore, regardless of industry type, the impact of new product capability on performance through market development capability is consistent. This supports our principal findings, indicating that the two capabilities are fundamentally essential capabilities to achieve a firm's superior performance (Stalk et al., 1992).

\section{Managerial implications}

\section{Strengthening the relationship pays off}

A firm can strategically consider entering into ITAs if its required resources do not reside in the local market or homogeneous industry. From a focal firm's perspective of ITAs, the resources obtained from its partners trigger innovation-creating capabilities which can lead to competitive advantage. As these resources outside of a firm's boundary complement its capabilities, the firm may depend on a partner's technology resources to fortify such capabilities. Given this, managers should make strategic decisions as to how to build trustworthy relationships with partners. By actively showing a willingness and eagerness to engage in partnerships, resources are more effectively transferred from the partners. Technological commitment can help the firm to surmount difficulties in the new product development process. If benefits from this kind of relational approach surpass those from protective relationship management, it will be pointless to put excessive controls on the relationships. Overly defensive approaches to relationship management may harm mutual trust built over time. Concerns over resource leakage are less of an issue in cross-industry ITAs owing to resource complementarity. Thus, alliance managers need to have an open mindset and a positive attitude towards opportunity generation via ITAs, aimed at new product development and the building of informal relationships with partners.

\section{From functional to cross-functional}

Senior managers in charge of alliance management should keep in mind that internationalization through strategic alliances contributes to the innovation of a firm. Also, alliance managers must be aware that cross-industry alliances enable firms to expedite technological product innovation process. The functional positions of alliance managers vary, depending on the organizational structures of individual firms. However, it is crucial that the alliance managers comprehensively understand the functional differences in the roles and activities of sub-business units (SBUs), such as R\&D, product management and marketing. Strategic alliance managers should actively monitor technology and market-related information in the market, contact the right partners, and build relationships to complement their own strategic resources with the resources requested SBUs. When aligned with corporate strategy, such external linkages as ITAs allow a firm to expand the range of available resources, but also to build its innovation ecosystems. Thus, ITAs provide firms with opportunities for incremental and radical innovation. It is also noteworthy that harmonization among SBUs guarantees improved product innovation. To overcome functional walls and silos within a firm, collaborations between SBUs are required, but they also ought to share strategic goals for their co-projects. Seamless communication among SBUs lessens information distortion in the 
innovation process. R\&D managers and product managers also have to acknowledge that technologically excellent products cannot be monetized without the commercial activities of business development and marketing managers. Without dysfunctional collaborations among the SBUs in a firm, superior technology resources can decay, leading to market failure. For this reason, alliance managers have to identify the diverse requirements (in terms of resources) of the functional SBUs. As such, as inter-unit mediators, alliance managers can play an active role in harmonizing the innovation process of their firm.

\section{Limitations and recommendations}

Like all research, our study has limitations. Firstly, our research setting is ITAs between SW and HW high-tech firms in the mobile computing market. We have not fully investigated the characteristics of these two different high-tech industries, due to the newness of the market. There are no significant sector differences between HW and SW firms in the structural model. Thus, we recommend that future cross-industry alliance research includes different industry settings, such as alliances between high-tech and low-tech industries. Secondly, we did not collect and analyze the data at the dyadic level. Although we made an attempt to investigate industry dyads between the SW and HW sectors from a focal firm's perspective, dyadic alliance research would be more useful in identifying the dynamics of resource governance in strategic alliances, from the perspectives of both partners. Thirdly, we include no antecedent of governance mechanisms in the model. We recommend that future research includes such a dimension in order to identify the dynamic factors that influence these mechanisms.

As for behavioral governance mechanisms in this paper, we only considered technological commitment and process control as representative behavioral governance mechanisms in ITAs. However, we cautiously speculate the regulatory focus of the allying firms' behaviors (e.g., promotion and prevention) during the ITA negotiation stage may also play a role in governance mechanisms, as ITAs are not always exogenously given (e.g., Das and Kumar, 2011; Kumar and Patriotta, 2011; Weber and Mayer, 2011; Weber et al., 2011). This line of regulatory focus in international strategic alliances can be expanded to an institutional study in the context of the high-tech industry (see e.g., Berry et al., 2010; Casper and Whitley, 2004; Jackson and Deeg, 2008; Whitley, 2012). For instance, Silicon Valley based firms fueled by entrepreneurs and venture capitalists (Hallen and Eisenhardt, 2012; Saxenian, 2007) and recently upgraded South Korean and Taiwanese high-tech firms shaped by industrial policy (Amsden, 2001; Chang, 1993) could have a different behavioral governance preference on an ITA at the early negotiation stage.

Regarding discussions of complementary versus substitutable governance mechanisms, our findings are explorative rather than confirmative in terms of the newness of the research context of cross-industry ITAs. In order to compare and test whether the two governance mechanisms are complementary or substitutes for each other, we recommend the use of a parameter-oriented covariance-based structural equation model. For the heterogeneity issue, we used the parametric approach. We recommend PLS researchers to adopt a finite mixture (FIMIX)-PLS method in order to capture unobserved heterogeneity in the overall model (Diamantopoulos and Siguaw, 2006; Gudergan et al., 2008; Hair et al., 2011b; Rigdon et al., 2011).

Next, in the survey, we used single informants drawn from exploratory interviews with senior managers, and reviews of the functional positions of pre-contacted informants, carried out through LinkedIn connections. However, managers' functional positions in strategic alliances and innovation may differ in individual organizations. Thus, it would be worth using multiple informants from different SBUs in a firm (e.g., R\&D, product development, business development, marketing). We also suggest that future research includes alliance performance, to identify how the outcomes of alliances affect firm-level business performance in ITAs, and vice versa. Finally, controlling for firm size and cultural distance in relation to various innovation contexts (e.g., process, incremental and radical innovation) would be valuable areas for further investigation, and are needed to understand the dynamic innovation phenomenon. 


\section{Appendix.}

Table A1. Demographic characteristics of respondent firms

\begin{tabular}{|c|c|c|}
\hline & Number of respondents & $\%$ \\
\hline \multicolumn{3}{|l|}{ Sales revenues in 2010} \\
\hline More than 9B USD & 9 & $8 \%$ \\
\hline $1 \mathrm{~B}$ USD - 9B USD & 11 & $10 \%$ \\
\hline $100 \mathrm{M}$ USD - 999M USD & 28 & $25 \%$ \\
\hline $10 \mathrm{M}$ USD $-100 \mathrm{M}$ USD & 23 & $21 \%$ \\
\hline $1 \mathrm{M}$ USD - 99USD & 16 & $15 \%$ \\
\hline Less than $1 \mathrm{M}$ USD & 3 & $3 \%$ \\
\hline No response & 20 & $18 \%$ \\
\hline Total & 110 & $100 \%$ \\
\hline \multicolumn{3}{|l|}{ Number of employees } \\
\hline More than 4,999 & 15 & $14 \%$ \\
\hline $1,000-4,999$ & 18 & $16 \%$ \\
\hline $500-999$ & 15 & $14 \%$ \\
\hline $250-499$ & 12 & $11 \%$ \\
\hline $50-249$ & 31 & $28 \%$ \\
\hline Less than 50 & 19 & $17 \%$ \\
\hline Total & 110 & $100 \%$ \\
\hline \multicolumn{3}{|l|}{ Alliance type } \\
\hline Joint R\&D agreement & 20 & $15 \%$ \\
\hline Co-development contract & 51 & $37 \%$ \\
\hline Mutual technology sharing & 18 & $13 \%$ \\
\hline Technology licensing & 32 & $23 \%$ \\
\hline Other types & 10 & $7 \%$ \\
\hline No agreement & 6 & $4 \%$ \\
\hline Total & $137^{\star}$ & $100 \%$ \\
\hline
\end{tabular}

Note: ${ }^{\star} 27$ respondents chose two types of alliance.

Table A2. Construct measurement, reliability and validity

$\begin{array}{lll}\text { Construct measures } & \text { Mean } \quad \text { SD } \quad \text { Outer loading }\end{array}$

Technological commitment (alpha $=0.763, \mathrm{CR}=0.828, \mathrm{AVE}=0.502)$

(strongly disagree $=1$, strongly agree 7 )

- Willing to make further investment in supporting this partner

- Willing to share industry trends and information with this partner

$\begin{array}{lll}4.709 & 1.336 & 0.508 \\ 5.264 & 1.072 & 0.776 \\ 4.745 & 1.443 & 0.522 \\ 5.464 & 1.209 & 0.826 \\ 5.673 & 1.126 & 0.833\end{array}$

- Make an honest effort to deliver on our promises to this partner

- Wish to technologically cooperate with this partner for a long time

Process control (alpha $=0.870, \mathrm{CR}=0.908, \mathrm{AVE}=0.713$ )

(strongly disagree $=1$, strongly agree 7 )

- Monitor to what extent this partner follows the agreed key terms

$\begin{array}{lll}4.955 & 1.237 & 0.743 \\ 5.009 & 1.208 & 0.877 \\ 5.282 & 1.174 & 0.910\end{array}$

- Monitor the product development process performed
- Monitor technology quality developed by this partner

(continued on next page) 


\begin{tabular}{|c|c|c|c|}
\hline Construct measures & Mean & SD & Outer loading \\
\hline - Monitor this partner's development milestone for our final deliverable & 5.300 & 1.162 & 0.838 \\
\hline \multicolumn{4}{|c|}{$\begin{array}{l}\text { New product development capability }(\text { alpha }=0.730, \mathrm{CR}=0.820, \mathrm{AVE}=0.481) \\
(\text { strongly disagree }=1, \text { strongly agree })\end{array}$} \\
\hline - Able to monitor technology resources in the market & 5.609 & 1.134 & 0.681 \\
\hline - Able to integrate new technology resources obtained from partners & 5.555 & 0.982 & 0.737 \\
\hline - Responsiveness to technology changes & 5.736 & 0.905 & 0.837 \\
\hline - Able to develop a series of new products constantly & 5.618 & 1.149 & 0.558 \\
\hline - Places emphasis on creativity in new product development & 5.709 & 1.112 & 0.622 \\
\hline \multicolumn{4}{|l|}{$\begin{array}{l}\text { Market development capability }(\text { alpha }=0.798, \mathrm{CR}=0.859, \mathrm{AVE}=0.550) \\
(\text { strongly disagree }=1 \text {, strongly agree } 7)\end{array}$} \\
\hline - Able to monitor and access customers preferences & 5.300 & 1.238 & 0.764 \\
\hline - Able to manage long-term customer relationships & 5.709 & 1.259 & 0.731 \\
\hline - Able to quickly introduce new products to the market & 4.991 & 1.411 & 0.683 \\
\hline - Able to develop creative marketing strategies for new products & 4.955 & 1.337 & 0.766 \\
\hline - Able to invest significant resources in marketing new products & 4.755 & 1.551 & 0.759 \\
\hline \multicolumn{4}{|l|}{$\begin{array}{l}\text { Business performance }(\text { alpha }=0.844, \mathrm{CR}=0.879, \mathrm{AVE}=0.510) \\
(\text { not very well }=1, \text { very well }=7)\end{array}$} \\
\hline - Sales growth & 5.073 & 1.239 & 0.738 \\
\hline - Increased profit & 4.827 & 1.284 & 0.595 \\
\hline - Market share growth & 4.973 & 1.145 & 0.724 \\
\hline - Increased number of official new products launched & 4.936 & 1.152 & 0.688 \\
\hline - Increased number of new customers & 5.155 & 1.068 & 0.754 \\
\hline - Increased reputation & 5.518 & 1.064 & 0.704 \\
\hline - Increased overall performance & 5.445 & 1.028 & 0.784 \\
\hline
\end{tabular}

\section{References}

Abernathy, W.J., Clark, K.B., 1985. Innovation: mapping the winds of creative destruction. Research Policy 14 (1), 3-22.

Adams, R., Bessant, J., Phelps, R., 2006. Innovation management measurement: a review. International Journal of Management Reviews 8 (1), 21-47.

Amsden, A.H., 2001. The Rise of the Rest: Challenges to the West from Late-Industrializing Economies. Oxford University Press, Oxford.

Anderson, E., Weitz, B., 1992. The use of pledges to build and sustain commitment in distribution channels. Journal of Marketing Research 29 (1), 18-34.

Armstrong, J.S., Overton, T.S., 1977. Estimating nonresponse bias in mail surveys. Journal of Marketing Research 14 (3), 396-402.

Atuahene-Gima, K., 2005. Resolving the capability - rigidity paradox in new product innovation. Journal of Marketing 69 (4), 61-83.

Aulakh, P.S., Kotabe, M., Sahay, A., 1996. Trust and performance in cross-border marketing partnerships: a behavioral approach. Journal of International Business Studies 27 (5), 1005-1032.

Bagozzi, R.P., Yi, Y., 1998. On evaluation of structural equation models. Journal of the Academy of Marketing Science 16 (1), 74-94.

Baldwin, J., Lin, Z., 2002. Impediments to advanced technology adoption for Canadian manufacturers. Research Policy 31 (1), 1-18.

Barclay, D., Higgins, C., Thompson, R., 1995. The partial least squares approach to casual modeling: personal computer adoption and use as illustration. Technology Studies 2 (2), 285-309.

Barney, J., 1991. Firm resources and sustained competitive advantage. Journal of Management 17 (1), 99-120.

Baron, R.M., Kenny, D.A., 1986. The moderator-mediator variable distinction in social psychological research: conceptual, strategic, and statistical considerations. Journal of Personality and Social Psychology 51, $1173-1182$. 
Becker, W., Dietz, J., 2004. R\&D cooperation and innovation activities of firms - evidence for the German manufacturing industry. Research Policy 33 (2), 209-223.

Berry, H., Guillen, M.F., Zhou, N., 2010. An institutional approach to cross-national distance. Journal of International Business Studies 41 (9), 1460-1480.

Berry, M.M.J., Taggart, J.H., 1994. Managing technology and innovation: a review. R\&D Management 24 (4), 341-353.

Birkinshaw, J., Sheehan, T., 2002. Managing the knowledge life cycle. MIT Sloan Management Review 44 (1), 75-83.

Blau, P.M., 1964. Exchange and Power in Social Life. J. Wiley, New York.

Bradley, F., 1999. International Marketing Strategy, third ed. London Financial Times Prentice Hall.

Brettel, M., Heinemann, F., Engelen, A., Neubauer, S., 2011. Cross-functional integration of R\&D, marketing, and manufacturing in radical and incremental product innovations and its effects on project effectiveness and efficiency. Journal of Product Innovation Management 28 (2), 251-269.

Burgers, J.H., Van Den Bosch, F.A.J., Volberda, H.W., 2008. Why new business development projects fail: coping with the differences of technological versus market knowledge. Long Range Planning 41 (1), $55-73$.

Calantone, R.J., Cavusgil, S.T., Zhao, Y., 2002. Learning orientation, firm innovation capability, and firm performance. Industrial Marketing Management 31 (6), 515-524.

Camison-Zornonza, C., Lapiedra-Alcami, R., Segarra-Cipres, M., Boronat-Navoarro, M., 2004. A metaanalysis-of innovation and organizational size. Organization Studies 25 (3), 331-361.

Cantwell, J., Narula, R., 2001. The eclectic paradigm in the global economy. International Journal of Economics of Business 8 (2), 155-172.

Carson, S.J., Madhok, A., Wu, T., 2006. Uncertainty, opportunism, and governance: the effects of volatility and ambiguity on formal and relational contracting. Academy of Management Journal 49 (5), $1058-1077$.

Casper, S., Whitley, R., 2004. Managing competences in entrepreneurial technology firms: a comparative institutional analysis of Germany, Sweden and the UK. Research Policy 33 (1), 89-106.

Chang, H.J., 1993. The political economy of industrial policy in Korea. Cambridge Journal of Economics 17 (2), 131-157.

Chesbrough, H.W., 2004. Managing open innovation. Research Technology Management 47 (1), $23-26$.

Chesbrough, H.W., 2007. Why companies should have open business models. MIT Sloan Management Review 48 (2), 22-28.

Chin, W.W., 1988. The partial least squares approach to structural equation modeling. In: Marcoulides, G.A. (Ed.), Modern Methods for Business Research. Lawrence Erlbaum, New Jersey, pp. 295-336.

Chin, W.W., 2010. How to write up and report PLS analyses. In: Vinzi, V.E., Chin, W.W., Henseler, J., Wang, H. (Eds.), Handbook of Partial Least Squares, first ed. Springer, Berlin, pp. 655-690.

Clark, K.B., Fujimoto, T., 1991. Product Development Performance: Strategy, Organization, and Management in the World Auto Industry, first ed. Harvard Business School Press, Boston.

Cohen, J., 1988. Statistical Power Analysis for the Behavioral Sciences, second ed. Lawrence Erlbaum, Hillsale.

Cohen, M.A., Eliashberg, J., Ho, T.-H., 1996. New product development: the performance and time-to-market tradeoff. Management Science 42 (2), 173-186.

Cohen, W.M., Levinthal, D.A., 1990. Absorptive capacity: a new perspective on learning and innovation. Administrative Science Quarterly 35 (1), 125-152.

Cooper, R.G., 2001. Winning at New Products, third ed. Basic Books, New York.

Cullen, J.B., Johnson, J.L., Sakano, T., 2000. Success through commitment and trust: the soft side of strategic alliance management. Journal of World Business 35 (3), 223-240.

Danneels, E., 2002. The dynamics of product innovation and firm competences. Strategic Management Journal 23 (12), 1095-1121.

Das, T.K., 2005. Deceitful behaviors of alliance partners: potential and prevention. Management Decision 43 (5), 706-719.

Das, T.K., Kumar, R., 2011. Regulatory focus and opportunism in the alliance development process. Journal of Management 37 (3), 682-708.

Das, T.K., Rahman, N., 2010. Determinants of partner opportunism in strategic alliances: a conceptual framework. Journal of Business and Psychology 25 (1), 55-74.

Das, T.K., Teng, B.-S., 2000. A resource-based theory of strategic alliance. Journal of Management 26 (1), 31-61.

Das, T.K., Teng, B.-S., 2001. Trust, control, and risk in strategic alliances: an integrated framework. Organization Studies 22 (2), 251-283. 
Day, G.S., 1994. The capabilities of market-driven organizations. Journal of Marketing 58 (4), 37.

Debruyne, M., Rudy, M., Griffin, A., Hart, S., Hultink, E.J., Robben, H., 2002. The impact of new product launch strategies on competitive reaction in industrial markets. Journal of Product Innovation Management 19 (2), 159-170.

Deligonul, S., Cavusgil, S.T., 2006. Legal versus relational ordering in channel governance: the case of the manufacturer and its foreign distributor. In: Solberg, C.A. (Ed.), 2006. Advances in International Marketing - Relationship between Exporters and their Foreign Sales and Marketing Intermediaries, vol. 16. Elsevier - JAI, Amsterdam, pp. 49-79.

Department of Trade and Industry, 2006. The 2006 R\&D Scoreboard, vol. 1. Department of Trade and Industry.

Dess, G.G., Robinson, R.B., 1984. Measuring organizational performance in the absence of objective measures: the case of the privately-held firm and conglomerate business unit. Strategic Management Journal 5 (3), 265-273.

Diamantopoulos, A., Siguaw, J.A., 2006. Formative versus reflective indicators in organizational measure development: a comparison and empirical illustration. British Journal of Management 17 (4), 263-282.

Dodgson, M., Gann, D., Salter, A., 2008. The Management of Technological Innovation, first ed. Oxford University Press, Oxford.

Dyer, J.H., Singh, H., 1998. The relation view: cooperative strategy and sources of international competitive advantage. Academy of Management Review 23 (4), 660-679.

Easingwood, C., Moxey, S., Capleton, H., 2006. Bringing high technology to market: successful strategies employed in the worldwide software industry. Journal of Product Innovation Management 23 (6), 498-511.

Eisenhardt, K.M., 1985. Control: organizational and economic approaches. Management Science 31 (2), 134-149.

Eisenhardt, K.M., Schoonhoven, C.B., 1996. Resource-based view of strategic alliance formation: strategic and social effects in entrepreneurial firms. Organization Science 7 (2), 136-150.

Eisenhardt, K.M., Tabrizi, B.N., 1995. Accelerating adaptive processes: product innovation in the global computer industry. Administrative Science Quarterly 40 (1), 84-110.

European Commission, 2003. The New SME Definition: User Guide and Model Declaration. European Commission, Brussels, Belgium.

Faems, D., Janssens, M., Madhok, A., van Looy, B., 2008. Toward an integrative respective on alliance governance: connecting contract design, trust dynamics, and contract application. Academy of Management Journal 51 (6), 1053-1078.

Falk, R.F., Miller, N.B., 1981. A Primer for Soft Modeling. The University of Akron Press, Akron.

Fornell, C., Cha, J., 1994. Partial least squares. In: Bagozzi, R.P. (Ed.), Advanced Methods of Marketing. Blackwell, Cambridge, pp. 55-78.

Fornell, C., Larcker, D.F., 1981. Evaluating structural equation models with unobservable variables and measurement error. Journal of Marketing Research 18 (1), 39-50.

Fritsch, M., Meschede, M., 2001. Product innovation, process innovation, and size. Review of Industrial Organization 19 (3), 335-350.

Gans, J.S., Stern, S., 2003. The product market and the market for "ideas": commercialization strategies for technology entrepreneurs. Research Policy 32 (2), 333-350.

Gassmann, O., Zeschky, M., Wolff, T., Stahl, M., 2010. Crossing the industry-line: breakthrough innovation through cross-industry alliances with 'non-suppliers'. Long Range Planning 43 (5-6), 639-654.

Gatignon, H., Xuereb, J.-M., 1997. Strategic orientation of the firm and new product performance. Journal of Marketing Research 34 (1), 77-90.

Geisser, S., 1975. The predictive sample reuse method with applications. Journal of the American Statistical Association 70 (350), 320-328.

Glaister, K.W., Buckley, P.J., 1996. Strategic motives for international alliance formation. Journal of Management Studies 33 (3), 301-332.

Goffin, K., Mitchell, R., 2005. Innovation Management, first ed. Palgrave Macmillan, New York.

Granovetter, M., 1985. Economic action and social structure: the problem of embeddedness. American Sociological Review 91 (3), 481-510.

Grant, R.M., Baden-Fuller, C., 2004. A knowledge accessing theory of strategic alliances. Journal of Management Studies 41 (1), 61-84.

Griffin, A., 1997. PDMA research on new product development practices: updating trends and benchmarking best practices. Journal of Product Innovation Management 14 (6), 429-458. 
Griffith, D.A., Cavusgil, S.T., Xu, S., 2008. Emerging themes in international business research. Journal of International Business Studies 39 (7), 1220-1235.

Gudergan, S.P., Ringle, C.M., Wende, S., Will, A., 2008. Confirmatory tetrad analysis in PLS path modeling. Journal of Business Research 61 (12), 1238-1249.

Gulati, R., Lavie, D., Singh, H., 2009. The nature of partnering experience and the gains from alliances. Strategic Management Journal 30 (11), 1213-1233.

Gulati, R., Nickerson, J.A., 2008. Interorganizational trust, governance choice, and exchange performance. Organization Science 19 (5), 688-708.

Gulati, R., Singh, H., 1998. The architecture of cooperation: managing coordination costs and appropriation concerns in strategic alliances. Administrative Science Quarterly 43, 781-814.

Gundlach, G.T., Achrol, R.S., Mentzer, J.T., 1995. The structure of commitment in exchange. Journal of Marketing 59 (1), 78-92.

Hagedoorn, J., Schakenraad, J., 1994. The effective of strategic technology alliances on company performance. Strategic Management Journal 15 (4), 291-309.

Hair, J.F., Ringle, C.M., Sarstedt, M., 2011a. PLS-SEM: indeed a silver bullet. Journal of Marketing Theory and Practice 19 (2), 139-152.

Hair, J.F., Sarstedt, M., Ringle, C., Mena, J., 2011b. An assessment of the use of partial least squares structural equation modeling in marketing research. Journal of the Academy of Marketing Science, 1-20.

Hair, J.F., Sarstedt, M., Ringle, C.M., Mena, J.A., 2012. An assessment of the use of partial least squares structural equation modeling in marketing research. Journal of the Academy of Marketing Science 40 (3), 414-433.

Hallen, B.L., Eisenhardt, K.M., 2012. Catalyzing strategies and efficient tie formation: how entrepreneurial firms obtain investment ties. Academy of Management Journal 55 (1), 35-70.

Heide, J.B., 1994. Interorganizational governance in marketing channels. Journal of Marketing 58 (1), 71-85.

Heide, J.B., Wathne, K.H., Rokkan, A.I., 2007. Interfirm monitoring, social contracts, and relationship outcomes. Journal of Marketing Research 44 (3), 425-433.

Henseler, J., Ringle, C.M., Sinkovics, R.R., 2009. The use of partial squares path modeling in international marketing. In: Sinkovics, R.R. (Ed.). In: Gharuri, P.N. (Ed.), New Challenges to International Marketing, vol. 20. Emerald JAI Press, Bingley, pp. 277-320.

Hill, C.W.L., Rothaermel, F.T., 2003. The performance of incumbent firms in the face of radical technological innovation. Academy of Management Review 28 (2), 257-274.

Hitt, M.A., Dacin, M.T., Levitas, E., Arregle, J.-L., Borza, A., 2000. Partner selection in emerging and developed market contexts: resource-based and organizational learning perspectives. Academy of Management Journal 43 (3), 449-467.

Hoetker, G., Mellewigt, T., 2009. Choice and performance of governance mechanisms: matching alliance governance to asset type. Strategic Management Journal 30 (10), 1025-1044.

Hulland, J., 1999. Use of Partial Least Squares (PLS) in strategic management research: a review of four recent studies. Strategic Management Journal 20 (2), 195-204.

Jackson, G., Deeg, R., 2008. Comparing capitalisms: understanding institutional diversity and its implications for international business. Journal of International Business Studies 39 (4), 540-561.

Jaworski, B., Kohli, A.K., Sahay, A., 2000. Market-driven versus driving markets. Journal of the Academy of Marketing Science 28 (1), 45-54.

Jaworski, B.J., 1988. Toward a theory of marketing control: environmental context, control types, and consequences. Journal of Marketing 52 (3), 23-39.

Jean, R.-J.B., Sinkovics, R.R., Cavusgil, S.T., 2010. Enhancing international customer-supplier relationships through it resources: a study of Taiwanese electronic suppliers. Journal of International Business Studies 41 (7), 1218-1239.

Kafouros, M.I., Buckley, P.J., 2008. Under what conditions do firms benefit from the research efforts of other organizations? Research Policy 37 (2), 225-239.

Kafouros, M.I., Buckley, P.J., Sharp, J.A., Wang, C., 2008. The role of internationalization in explaining innovation performance. Technovation $28(1-2), 63-74$.

Keil, M., Tan, B.C.Y., Wei, K.-K., Saarinen, T., Tuunainen, V., Wassenaar, A., 2000. A cross-cultural study on escalation of commitment behavior in software projects. MIS Quarterly 24 (2), 299-325.

Kim, K., Frazier, G.L., 1997. Measurement of distributor commitment in industrial channels of distribution. Journal of Business Research 40 (2), 139-154. 
Kirner, E., Kinkel, S., Jaeger, A., 2009. Innovation paths and the innovation performance of low-technology firms - an empirical analysis of German industry. Research Policy 38 (3), 447-458.

Kirsch, L.J., Sambamurthy, V., Ko, D.-G., Purvis, R.L., 2002. Controlling information systems development projects: the view from the client. Management Science 48 (4), 484-498.

Kleinschmidt, E.J., Cooper, R.G., 1991. The impact of product innovativeness on performance. Journal of Product Innovation Management 8 (4), 240-251.

Kotabe, M., Srinivasan, S.S., Aulakh, P.S., 2002. Multinationality and firm performance: the moderating role of R\&D and marketing capabilities. Journal of International Business Studies 33 (1), 79-97.

Kotabe, M., Swan, K.S., 1995. The role of strategic alliances in high-technology new product development. Strategic Management Journal 16 (8), 621-636.

Koza, M.P., Lewin, A.Y., 1998. The co-evolution of strategic alliance. Organization Science 9 (3), 255-263.

Kraaijenbrink, J., Spender, J.-C., Groen, A.J., 2010. The resource-based view: a review and assessment of its critiques. Journal of Management 36 (1), 349-372.

Kumar, N., Scheer, L.K., Steenkamp, J.-B.E.M., 1995. The effects of perceived interdependence on dealer attitudes. Journal of Marketing Research 32 (3), 348-356.

Kumar, R., Patriotta, G., 2011. Culture and international alliance negotiations: a sensemaking perspective. International Negotiation 16 (3), 511-533.

Lavie, D., 2006. The competitive advantage of interconnected firms: an extension of the resource-based view. Academy of Management Review 31 (3), 638-658.

Lavie, D., Lechner, C., Singh, H., 2007. The performance implications of timing of entry and involvement in multipartner alliances. Academy of Management Journal 50 (3), 578-604.

Lee, R., 2009. Social capital and business and management: setting a research agenda. International Journal of Management Reviews 11 (3), 247-273.

Lee, Y., Cavusgil, S.T., 2006. Enhancing alliance performance: the effects of contractual-based versus relational-based governance. Journal of Business Research 59 (8), 896-905.

Lew, Y.K., Sinkovics, R.R., 2012. Practices in mobile computing alliances. In: Harris, S., Kuivalainen, O., Stoyanova, V. (Eds.), International Business - New Challenges, New Forms, New Perspectives. Palgrave MacMillan, Houndmill, Basingstoke, UK, pp. 242-261.

Li, D., Ferreira, M.P., 2008. Partner selection for international strategic alliance in emerging economics. Scandinavian Journal of Management 24 (4), 308-319.

Li, H., Atuahene-Gima, K., 2002. The adoption of agency business activity, product innovation, and performance in Chinese technology ventures. Strategic Management Journal 23 (6), 469-490.

Liao, T.-S., Rice, J., 2010. Innovation investments, market engagement and financial performance: a study among Australian manufacturing SMEs. Research Policy 39 (1), 117-125.

Lichtenthaler, U., 2008. Integrated roadmaps for open innovation. Research Technology Management 51 (3), 45-49.

Littler, D., 1994. Marketing and innovation. In: Dodgson, M., Rothwell, R. (Eds.), The Handbook of Industrial Innovation. Edward Elgar, Aldershot, pp. 106-141.

Lunn, J., 1987. An empirical analysis of firm process and product patenting. Applied Economics 19, $743-751$.

Luo, Y., 2005. How important are shared perceptions of procedural justice in cooperative alliances? The Academy of Management Journal 48 (4), 695-709.

Lusch, R.F., Brown, J.R., 1996. Interdependency, contracting, and relational behavior in marketing channels. Journal of Marketing 60 (4), 19-38.

Madhok, A., 1995. Opportunism and trust in joint venture relationships: an exploratory study and model. Scandinavian Journal of Management 11 (1), 57-74.

Madhok, A., 2006. Revisiting multinational firms' tolerance for joint ventures: a trust-based approach. Journal of International Business Studies 37, 30-43.

Mayer, K.J., Argyres, N.S., 2004. Learning to contract: evidence from the personal computer industry. Organization Science 15 (4), 394-410.

Mayer, K.J., Salomon, R.M., 2006. Capabilities, contractual hazards, and governance: integrating resourcebased and transaction cost perspectives. Academy of Management Journal 49 (5), 942-959.

Mesquita, L.F., Anand, J., Brush, T.H., 2008. Comparing the resource-based and relational views: knowledge transfer and spillover in vertical alliances. Strategic Management Journal 29 (9), 913-941.

Miller, D., 1987. The Structural and environmental correlates of business strategy. Strategic Management Journal 8 (1), 55-76. 
Morgan, R.M., Hunt, S.D., 1994. The commitment-trust theory of relationship marketing. Journal of Marketing 58 (3), 20-38.

Mowery, D.C., Oxley, J.E., Silverman, B.S., 1996. Strategic alliances and interfirm knowledge transfer. Strategic Management Journal 17 (Winter Special Issue), 77-91.

Narula, R., Hagedoorn, J., 1999. Innovating through strategic alliances: moving towards international partnerships and contractual agreements. Technovation 19 (5), 283-294.

Neelankavil, J.P., Alaganar, V.T., 2003. Strategic resource commitment of high-technology firms: an international comparison. Journal of Business Research 56 (6), 493-502.

Newbert, S.L., 2008. Value, rareness, competitive advantage, and performance: a conceptual-level empirical investigation of the resource-based view of the firm. Strategic Management Journal 29 (7), 745-768.

Norman, P.M., 2004. Knowledge acquisition, knowledge loss, and satisfaction in high technology alliances. Journal of Business Research 57 (6), 610-619.

Oliver, C., 1997. Sustainable competitive advantage: combining institutional and resource-based views. Strategic Management Journal 18 (9), 697-713.

Osborn, R.N., Baughn, C.C., 1990. Forms of interorganizational governance for multinational alliances. Academy of Management Journal 33 (3), 503-519.

Osborn, R.N., Hagedoorn, J., 1997. The Institutionalization and evolutionary dynamics of interorganizational alliance and networks. Academy of Management Journal 40 (2), 261-278.

Oxley, J.E., 1997. Appropriability hazards and governance in strategic alliances: a transaction cost approach. Journal of Law and Economics, \& Organization 13 (2), 387-409.

Oxley, J.E., Sampson, R.C., 2004. The scope and governance of international R\&D alliances. Strategic Management Journal 25 (8/9), 723-749.

Pagell, M., Krause, D.R., 2004. Re-exploring the relationship between flexibility and the external environment. Journal of Operations Management 21 (6), 629-649.

Pitelis, C.N., 2007. A behavioral resource-based view of the firm: the synergy of Cyert and March (1963) and Penrose (1959). Organization Science 18 (3), 478-490.

Podsakoff, P.M., Organ, D.W., 1986. Self-reports in organizational research: problems and prospects. Journal of Management 12 (4), 531-544.

Poppo, L., Zenger, T., 2002. Do formal contracts and relational governance function as substitutes or complement? Strategic Management Journal 23 (8), 707-725.

Ramaswami, S.N., Srivastava, R.K., Bhargava, M., 2009. Market-based capabilities and financial performance of firms: insights into marketing's contribution to firm value. Journal of the Academy of Marketing Science 37 (2), 97-116.

Rigdon, E.E., Ringle, C.M., Sarstedt, M., Gudergan, S.P., 2011. Assessing heterogeneity in customer satisfaction studies: across industry similarities and within industry difference. In: Sarstedt, M., Schwaiger, M., Taylor, C.R. (Eds.), 2011. Measurement and Research Methods in International Marketing, vol. 22. Emerald Group, Bingley, UK, pp. 169-194.

Ringle, C.M., Wende, S., Will, A., 2005. SmartPLS, vol. 2011. SmartPLS, Hamburg, Germany.

Robertson, T.S., Gatignon, H., 1998. Technology development mode: a transaction cost conceptualization. Strategic Management Journal 19 (6), 515-531.

Saxenian, A., 2007. The New Argonauts: Regional Advantage in a Global Economy. Harvard University Press, Cambridge, MA.

Schumpeter, J.A., 1943. Capitalism, Socialism, and Democracy. George Allen and Unwin, London.

Sinkovics, R.R., Jean, R.-J.B., Pezderka, N., 2010. Cross-border relationships and performance: revisiting a complex linkage - a commentary essay. Journal of Business Research 63 (12), 1368-1371.

Song, M., Droge, C., Hanvanich, S., Calantone, R., 2005. Marketing and technology resource complementarity: an analysis of their interaction effect in two environmental contexts. Strategic Management Journal 26 (3), 259-276.

Song, X.M., Parry, M.E., 1997. The determinants of Japanese new product successes. Journal of Marketing Research 34 (1), 64-76.

Spanos, Y.E., Lioukas, S., 2001. An examination into the causal logic of rent generation: contrasting porter's competitive strategy framework and the resource-based perspective. Strategic Management Journal 22 (10), 907-934.

Stalk, G., Evans, P., Shulman, L.E., 1992. Competing on capabilities: the new rules of corporate strategy. Harvard Business Review 70 (2), 57.

Stanley, F.S., 2008. Learning how to be innovative. Business Strategy Review 19 (4), 46-51. 
Stone, M., 1974. Cross-validatory choice and assessment of statistical predictions. Journal of the Royal Statistical Society, Series B (Methodological) 36 (2), 111-147.

Stuart, T.E., 2000. Internationalization alliance and the performance of firms: a study of growth and innovation rates in a high-technology industry. Strategic Management Journal 21 (8), 791-811.

Teece, D.J., Pisano, G.P., 1994. The dynamic capabilities of firms: an introduction. Industrial and Corporate Change 3 (3), 537-556.

Tenenhaus, M., Vinzi, V.E., Chatelinc, Y.-M., Laurob, C., 2005. PLS path modeling. Computational Statistics \& Data Analysis 48 (1), 159-205.

Teng, B.-S., Das, T.K., 2008. Governance structure choice in strategic alliances. Marketing Decision 46 (5), $725-742$.

Uzzi, B., 1997. Social structure and competition in interfirm networks: the paradox of embeddedness. Administrative Science Quarterly 42 (1), 35-67.

Venkatraman, N., Ramanujam, V., 1986. Measurement of business performance in strategy research: a comparison of approaches. Academy of Management Review 11 (4), 801-814.

Vorhies, D.W., Morgan, R.E., Autry, C.W., 2009. Product-market strategy and the marketing capabilities of the firm: impact on market effectiveness and cash flow performance. Strategic Management Journal 30 (12), 1310-1334.

Weber, L., Mayer, K.J., 2011. Designing effective contracts: exploring the influence of framing and expectations. Academy of Management Review 36 (1), 53-75.

Weber, L., Mayer, K.J., Macher, J.T., 2011. An analysis of extendibility and early termination provisions: the importance of framing duration safeguards. Academy of Management Journal 54 (1), 182-202.

White, S., Lui, S.S.-Y., 2005. Distinguishing costs of cooperation and control in alliances. Strategic Management Journal 26 (10), 913-932.

Whitley, R., 2012. Internationalization and the institutional structuring of economic organization: changing authority relations in the twenty-first century. In: Morgan, G., Whitley, R. (Eds.), Capitalisms and Capitalism in the Twenty-first Century. Oxford University Press, Oxford, pp. 211-236.

Williamson, O.E., 1979. Transaction-cost economics: the governance of contractual relations. Journal of Law and Economics 22 (2), 233-261.

Williamson, O.E., 1991. Comparative economic organization: the analysis of discrete structural alternatives. Administrative Science Quarterly 36 (2), 269-296.

Wold, H., 1975. Path models with latent variables: the NIPALS approach. In: Blalock, H.M., Aganbegian, A., Borodkin, F.M., Boudon, R., Capecchi, V. (Eds.), Quantitative Sociology. Academic, New York, pp. 307-359.

Wu, F., Sinkovics, R.R., Cavusgil, S.T., Roath, A.S., 2007. Overcoming export manufacturers' dilemma in international expansion. Journal of International Business Studies 38 (2), 283-302.

Zaheer, A., Venkatraman, N., 1995. Relational governance as an interorganizational strategy: an empirical test of the role of trust in economic exchange. Strategic Management Journal 16, 373-392.

Zahra, S.A., Ireland, R.D., Hitt, M.A., 2000. International expansion by new venture firms: international diversity, mode of market entry, technological learning, and performance. Academy of Management Journal 43 (5), 925-950.

Zhou, K.Z., Wu, F., 2010. Technological capability, strategic flexibility, and product innovation. Strategic Management Journal 31 (5), 547-561.

\section{Biographies}

Yong Kyu Lew is Lecturer (Assistant Professor) in International Business at Hull University Business School of University of Hull, UK. He received his PhD from Manchester Business School, The University of Manchester, UK. His research focuses on international strategic alliances, interfirm governance, and innovation in high-tech industries. E-mail: y.lew@hull.ac.uk

Rudolf R. Sinkovics is Professor of International Business at Manchester Business School, UK, where he is currently head of the Comparative and International Business Group and Director of MBS-CIBER. His research is focused on inter-organizational governance, the role of ICT in firm internationalization, and research methods in international business. He received his PhD from the Vienna University of Economics and Business Administration (WU-Wien), Austria. His work has been published in international business and international marketing journals. E-mail: Rudolf.Sinkovics@manchester.ac.uk, Web: http://www.personal.mbs.ac.uk/rsinkovics 